\title{
TRIANGULATING BLAKE, WHITMAN, AND GINSBERG
}

\author{
GARY SCHMidgall
}

I HAVE JUST SPENT the last several years seeking to tease out Walt Whitman's relationship to several members of the British literary pantheon, most notably Shakespeare, Milton, Burns, Blake, and Wordsworth. The result-Containing Multitudes: Walt Whitman and the British Literary Tradition (Oxford University Press, 2014)—could be described as an attempt to imagine how Whitman would have felt if he had actually voyaged to Great Britain and visited Westminster Abbey's Poets' Corner, where all five of these authors are honored. As I neared completion of the project, I thought it would be appropriate to read again, after four decades, Harold Bloom's provocative and magisterial The Anxiety of Influence (1973), and I was gratified to be reminded of how daunting he makes the task of identifying and measuring influence: "Criticism is the art of knowing the hidden roads that go from poem to poem." $\mathrm{My}$ task, of course, was rendered more difficult because Whitman seems to have made some concerted effort to camouflage those hidden roads that might link him to his forebears. In an unsigned self-review of the 1855 Leaves, he declared that he was making "no allusions to books or writers; their spirits do not seem to have touched him."' Beyond the influences, also worth exploring are the simple (or complex) affinities that the latecoming Whitman shared with his poet-forerunners. The Danish scholar Frederik Schyberg, in his 1933 study Walt Whitman (an English translation appeared in 1951), eloquently warned, "In the relationships of literary history, the influence of one author on another is only half the story, and often the least interesting." $3 \mathrm{He}$ adds that it is also possible to "find Whitmanesque poets even in the literature preceding him." This is an old idea. In his Religio Medici (1643), Thomas Browne wrote, "Men are lived over again... . There was none then but there hath been someone since that parallels him, and is, as it were, his revived self." 4

I experienced this déjà $v u$ feeling often in my research, but perhaps nowhere more strikingly than in the case of William Blake, Walt Whitman, and Allen Ginsberg. Their chief affinity is not prosodic (though all three reveled in the long line), but rests in their being exuberantly subversive outliers in the culture and society in which they lived. Radical individualism, courageously asserted, propelled them: all three were 
vigorously counter-cultural. During the course of teaching a graduate seminar on Whitman and Ginsberg, I became particularly conscious of how often the latter acknowledged Blake and Whitman as inspirational for his relentless demolition of culture and society (and literature) in post-World War II America. The comprehensive interrogation of English culture in 1789-1820 that Blake produced in his Songs of Innocence and Experience and several prophetic poems was repeated for America a half-century later by Whitman, and Ginsberg gaily rehearsed the process for 1950s and 1960s America in several of his collections. These three poets identified the same social and literary foibles in their countrymen, and this produced remarkably similar targets for their fury. While completing my chapter on Blake for Containing Multitudes, I also became aware of the hidden roads that connect, say, Blake's last prophetic poem Ferusalem (1804-1820), Whitman's “Song of Myself” or his 1870 screed Democratic Vistas, and Ginsberg's "Howl" (1955-56). (The hidden road can be traced back much further, of course-for instance, to Book One of Sir Thomas More's Utopia [1516], which also castigated a nation's political and economic culture.) What follows is but a preliminary suggestion of some of the ways Ginsberg can be seen as having "lived over again" the legacy of Blake and Whitman.

Among the very first persons to note the likeness of William Blake and Walt Whitman was a member of Walt's own circle, John Swinton, whose brother William was a perceptive early reviewer of Leaves of Grass. On September 27, 1868, Whitman wrote to William O'Connor, telling him that Swinton was saying "the formal resemblance between several pieces of Blake, \& my pieces, is so marked that he, $S$, has, with persons that partially know me, passed them off temporarily for mine, \& read them aloud as such. He asked me pointedly whether I had not met with Blake's productions in my youth." ${ }^{\prime 5}$ The question of connection between the two poets had recently been ignited by publication of the fiery young poet and critic Algernon Swinburne's book William Blake: A Critical Study (1868), a first clarion hurrah for the poet-engraver (this was five years after the first Blake biography, by Alexander Gilchrist, appeared). Swinburne chose to end his 300-page paean with a threepage peroration comparing Blake and Whitman: "The points of contact and sides of likeness between William Blake and Walt Whitman are so many and so grave, as to afford some ground of reason to those who preach the transition of souls or transfusion of spirits." He concludes by saying of "Out of the Cradle Endlessly Rocking" and "When Lilacs Last in the Dooryard Bloom'd" that "in breadth of outline and charm of colour, these poems recall the work of Blake; and to neither poet can a higher tribute of honest praise be paid than this."

Edith Sitwell captured their mystical and prophetic likenesses when she observed of Blake and Whitman, "Both were Pentecostal Poets. 
The Tongues of Fire had descended upon them" (the church festival of Pentecost commemorates the visitation of the Holy Spirit to Christ's disciples). ${ }^{7}$ Her view might well be supported by drawing attention to the remark Blake made in a letter to a patron, "Dear Sir, excuse my enthusiasm or rather madness, for I am really drunk with intellectual vision whenever I take a pencil or graver into my hand"-or when Whitman writes, "Through me the afflatus surging and surging, through me the current."

Other authors might be added to those who have sensed the camaraderie of Blake and Whitman. That the firebrand, Orc-spirited Frenchman André Gide-Orc is the spirit of revolution in Blake's prophecies - translated both Whitman and Blake (and also their transvaluing soul-mate Friedrich Nietzsche) can come as no surprise. ${ }^{9}$ The Gilded Age arts critic James Gibbons Huneker even wryly suggested that Whitman "imitated Ossian and Blake, and their singing robes ill-befitted his burly frame."10 William Michael Rossetti (1829-1919), a critic and a founding member of the Pre-Raphaelite Brotherhood, stands out as a perfect example of this spiritual affinity. He figured crucially in the early blossoming of Blake's reputation in the 1860s, assisting Anne Gilchrist in posthumously publishing the 1863 Life and its accompanying anthology of selections, then encouraging Swinburne's Blake study, which was dedicated to him. Rossetti's own edition of The Poetical Works of William Blake would appear several times, beginning in 1875. His first service to Whitman was the first London edition, the Poems of 1868, which appeared the same year from the same publisher as Swinburne's William Blake. He also excited Anne Gilchrist's interest in Whitman, urged her to write $A$ Woman's Estimate, and guided it to publication. Later in the 1880 s, they joined to mount a subscription campaign to benefit Whitman; Rossetti's last letter to Anne before her death in 1885 was to say he had sent the sum of $£ 21.2 .6$ to Camden by postal order. ${ }^{11}$

But surely the most resonant way to tie Blake and Whitman together is to turn to a poet who most fervently and eloquently idolized both of them: Allen Ginsberg (1926-1997). The gemini likenesses of Whitman and Blake are often asserted by him, and these two poets are certainly mentioned by him in his poems, prose, and letters more frequently than any other poets. Perhaps most strikingly, they figure in his assertions of his own heroic-prophetic vocation. In the liner notes for a 1969 recording of musical settings of Blake's Songs, he rousingly asserts, "the soul of the planet is wakening, the time of dissolution of material forms is here, our generation's trapped in imperial satanic cities and nations, and only the prophetic priestly consciousness of the bard-Blake, Whitman or our own new selves - can steady our gaze into the fiery eyes of the tygers of the wrath to come."12 Ten years later he summed himself up during his youthful phase as a poet "of prophecy, 
part Blakean inspiration, part ordinary mind from Whitman - that is to say, the poet who speaks from his frank heart in public speaks for all hearts. "Who touches this book touches a man"' (DP 212).

Perhaps Ginsberg's most emphatic identification with the spiritseeking, politically revolutionary tradition of Blake and Whitman was penned for the Village Voice in the volatile year of 1968:

By the late ' 40 s of this memory century the people I knew best and loved most had already broken thru the crust of old reasons and were dowsing for some supreme reality ... Blake had called 'O Earth O Earth return!' [Introduction to Songs of Experience, WB 18] centuries before, echoing the ancient gnostic prophecy that Whitman spelled out for America specifically demanding that the steam engine "be confronted and met by at least an equally subtle and tremendous force infusion for purposes of spiritualization, for the pure conscience, for genuine aesthetics, and for absolute and primal manliness and womanliness." $(\text { DP 108) })^{13}$

The quoted Whitman words are, to judge by how often Ginsberg echoed them, from a favorite passage in Democratic Vistas. ${ }^{14}$ "Force infusion" is an apt phrase to describe the renovation Blake envisioned for Albion/ England at the end of ferusalem: a transformation of the Satanic-Urizenic "Furnaces of affliction" into "Fountains of Living Waters flowing from the Humanity Divine" (WB 256). Donald Pease has called Leaves of Grass "an epic prophecy" in the tradition of Blake, its purpose being "to deliver the consciousness of England from the 'conventional systems' which had entrapped it for centuries." 15 Ginsberg, eager to deliver American consciousness from post-World War II political, corporate, and military systems, vigorously embraced Blake's vision of a new Albion in Ferusalem and Whitman's new vision for These States in Democratic Vistas. $\mathrm{He}$ pressed his own transformation of American poetry as well as a raising of consciousness. His declaration in his aptly titled "Ego Confession" is in the revolutionary Blake and Whitman style: "I want to be a spectacle of Poesy triumphant over trickery in the world." ${ }^{16}$ Pertinent here is Blake's vow, quoting Ephesians, at the opening of Vala, or The Four Zoas to "wrestle" with "the rulers of the darkness of this world" (WB 300). In 1987 , Ginsberg gave the two poets pride of place when, in a wry poemas-personals-ad, the "Poet professor in autumn years" reveals that he was "empowered by Whitman Blake Rimbaud Ma Rainey \&Vivaldi" (CP 970).

If there is an equivalent to Whitman's withering prescription in Democratic Vistas for treating a "cankered, crude, superstitious, and rotten" American society (11), it is surely Blake's short, dismal early prophecy, The Book of Urizen (1794), with its "petrific" realm of "dark contemplation" (WB 72). In a 1988 pamphlet titled "Your Reason and Blake's System," Ginsberg responded to Urizen with revealing enthusiasm, calling it "Blake's first deep probe into the ultimate nature of 
the psyche in the creation of consciousness" and a "book of Genesis for consciousness itself" (DP 282). Among Whitman's poems, "Song of Myself" could be said to perform a similar function. Blake's Urizen"unprolific, / Self-clos'd, all-repelling" ... "In chains of the mind locked up" . . . "cold" in the "dreamless night" under a "petrific" roof-is the equivalent of all the "inertness and fossilism" Whitman found in his post-Civil War America (DV 26). All of which reminded Ginsberg of the great "1970s problem" of living in the age of the nuclear bomb: "The paranoiac, self-limiting, territorial, comparing, reasoning, Urizenic mentality of the armaments makers and the Pentagon argues and pushes for defense against self-begotten armies." Ginsberg's analysis of "the present Western industrial situation is that hyper-rationalism, Urizen, has taken over" (DP 280-281).

The enemy of Urizen in Blake is the revolutionary babe Orc, and the spirit of Orc resided in Whitman as it did in Ginsberg: the primal political agon at the Democratic National Convention in Chicago in 1968 was one of Orc (the spirit of subversive protest) versus Urizen (politics as usual). Ginsberg was thrilled that Blake called Urizen "unprolific" because it gave America's prophet-poet an opening to attack his enemies: “That's really great! Urizen is unprolific. He can't write poetry, he can't create anything, all he can do is criticize" (DP 282). Here Ginsberg might well have recalled Whitman's memorable evocation of creative energy in "Song of Myself" (sec. 3): "Urge and urge and urge,/ Always the procreant urge of the world" ( $L G 30)$. Ginsberg goes on to add, "Poetic imagination always escapes Urizen in Blake's scheme" (DP 282). Urizen, he sums up, "is one of Blake's really hard, tough, mental, dryseed works - the poetry is terrific." After composing it, Blake "unfolds his primordial mind and becomes mighty, rhetorically beautiful, golden tongued and syllabically interesting. Vowels become roarers and exquisite philosophic rhapsodies are introduced, that later turn visionary in Milton [c. 1804-c. 1811] and throughout ferusalem" (284).

Ginsberg's last sentence in "Your Reason and Blake's System" is: "Blake was astonished by his own imagination" (DP 284). Whitman confessed to the same astonishment in the last year of his life: "Leaves of Grass is a mystery to me," he told Horace Traubel, "I do not pretend myself to have solved it - not at all." Then he added, "I . . . often stand in astonishment before the book - am defeated by it - lost in its curious revolutions, its whimsies, its overpowering momentum-lost as if a stranger" ( $W W C$ 8:321). Ginsberg sought to astonish America with his imagination as well. Careering through the midwest in a Volkswagen bus during a rowdy tour of college readings in 1966, he declared himself a modern Blake, "I call all Powers of imagination/ to my side in this auto to make Prophecy" (CP 414). 
Ginsberg's affinities with Whitman are well-known; those with Blake perhaps deserve more emphasis, particularly his visionary appearance to Ginsberg in the summer of 1948 . While lazing with a volume of Blake in his East Harlem apartment after masturbating, Blake's voice rose from the book reciting "Ah! Sun-flower" from Songs of Experience. Twelve years later in 1960, in "Psalm IV," Ginsberg could still summon up a vivid memory of his vision of Blake's "great brain unfolding." It was a profound personal epiphany. Wittily alluding to Sir Thomas Wyatt's $16^{\text {th }}$-century lyric "They Flee from Me," he recalled, "It was no dream, I lay broad waking on a fabulous couch in Harlem." He

heard a voice, it was Blake's, reciting in earthen measure:

the voice rose out of the page to my secret ear never heard

before...

And Blake's voice in the vision says: "Love! thou patient presence \& bone of the body" (CP 246). The message of love-thoroughly Blakean (and Whitmanic) - is perhaps best captured at the opening of ferusalem when the "Spirit of Jesus" utters his "mild song": "I am in you and you in me, mutual in love divine:/ Fibres of love from man to man thro Albions pleasant land" (WB 146). "Psalm IV" ends on an ecstatic note: "Time howled in anguish in my ear" - a reminder that a Blakean visionary ecstasy may also be present in his earlier poem "Howl."

Ginsberg proclaimed the Blakean message of tolerance and magnanimity in the not so pleasant land of 1950s America. Even before "Howl," he had declared it in a poem written in 1954 and called, in Blake and Whitman fashion, "Song": "The weight of the world/ is love ... the burden of life/ is love" (CP 119). Thirty-eight years later he could still say with justice in the poem "After Lalon," "If I had a mind it got/ covered with Love" (CP 1020). All of which amounts to a paraphrase, whether conscious or not, of Whitman's "a kelson of the creation is love" in "Song of Myself" ( $L G$ 32).

The 1948 Blake visitation was seminal for Ginsberg. He returned to it in his short 1973 poem "Who":

\footnotetext{
From the Great Consciousness vision Harlem 1948 buildings standing in eternity

I realized entire Universe was manifestation of One Mind-

My teacher was William Blake-my life work Poesy,

transmitting that spontaneous awareness to Mankind. (CP 603)
}

Several memorable Whitman lines echo here: "Beginning my studies ... The mere fact consciousness ... pleas'd me so much"; "Me imperturbe, standing at ease in Nature"; he praised the "equable" poet who "sees 
eternity in men and women"; he said he "heard what was said of the universe"; his life work was also "uttering joyous leaves" of Poesy; "Spontaneous me," he boasted, warbling "spontaneous songs recluse to myself."

Two decades later, in 1992, Ginsberg recalled again Blake's visitation:

It's true I got caught in

the world

When I was young Blake

tipped me off

Other teachers followed ... (“After Lalon," CP 1019)

The vision, of course, charmingly mimics the visions Blake confided to his friends. In fact, Ginsberg made a 1979 pilgrimage to the village of Felpham to see the garden where a little girl named Ololon and Milton himself had appeared to Blake, inspiring his Milton. ${ }^{17}$ In his biography, Morgan writes that Ginsberg's visions were "suspiciously questioned and condemned all around"-Blake's fate too! His father, recently apprised of his son's homosexuality, jumped to the conclusion that he was going insane, and Ginsberg himself was open enough to this possibility to voluntarily enter a New York State psychiatric hospital for several months in 1949. Soon enough, Ginsberg came to the same conclusion as the plucky defenders of those "insane" and eccentric geniuses Blake and Whitman: in a mad, mad, One-Flew-Over-the-Cuckoo's-Nest world it is too easy to declare an inspired seer to be non compos mentis. In 1978, he looked back on his early years: "I did not exactly plan a large persona though it was within literary bounds set by Walt Whitman and other sympathetic precursors." Blake, obviously, was one of these precursors. "RimbaudWhitman, mad sanity, was my ideal," Ginsberg wrote in 1978 (DP 211).

Numerous hallmarks of the Blake-and-Whitman ethos are reiterated by Ginsberg. Like them he was an awakening force: Blake's ferusalem was conceived to "awake Albion from his long \& cold repose" (WB 159), while Whitman intended to shake the "unwaked sonnambules" reading his Leaves into an awareness of "the core of life, namely happiness" ("Thought"). In the early "70s Ginsberg looked back: "I remember the sleepless epiphanies of 1948-everywhere in America brain-consciousness was waking up" (DP 355). Just as Blake and Whitman roused nations that had fallen into post-revolutionary sloughs of despond, Ginsberg called himself a prophet too, but with a wryly Pentagon-esque turn of phrase: "I am the defense early warning radar system" ("Death to Van Gogh's Ear," CP 176). Ginsberg also became a brilliant speaker of truth to masquerading Urizenic power, in which vocation he explicitly tied himself to Blake and Whitman. He wrote on July 4th in 1959: 
The stakes are too great - an America gone mad with materialism, a police-state America, a sexless and soulless America prepared to battle the world in defense of a false image of its authority. Not the wild and beautiful America ofthe comrades of Walt Whitman, not the historic America of William Blake and Henry David Thoreau where the spiritual independence of each individual was an America, a universe, more huge and awesome than all the abstract bureaucracies and authoritative officialdoms of the world combined. (DP 5)

Ginsberg sensed in 1988 that Blake's prophetic books "are useful now as explorations of the same problems we have, somewhat related to the revolutionary fervor of the sixties in America and a subsequent so-called 'disillusionment.' So actually Blake is up to date in the psychology of wrath vs. pity, compassion vs. anger, that runs through all of his work and is visible in our own decade as well as his" (DP 279). "America when will you be angelic?" Ginsberg asked in his scornful Juvenalian tirade of 1956 titled "America" (CP 154). Blake asked the same question about England in Urizen and ferusalem, just as Whitman asked it in Democratic Vistas, where he attacked the "hollowness at heart," the "atmosphere of hypocrisy," and "scornful superciliousness" of post-Civil War America (11).

All of Blake and Whitman is premised on a free body and soul unconstrained by "mind-forged manacles." As the former wrote in his sermon "To the Christians" in ferusalem, "I know of no other Christianity and of no other Gospel than the liberty both of body \& mind to exercise the Divine Arts of Imagination" (WB 231). Ginsberg pinpoints his own entry into such freedom as being facilitated by our two poets: "At seventeen something shook me loose from the authoritarianism of the culture and from the authority of Columbia [University]. I think it was the jailing of a friend, who I loved, who knew Jack [Kerouac] well. And then also I was interested in Rimbaud and Whitman, and I had met [William] Burroughs by then, I was getting teaching from Burroughs that included Blake" (SM 306-307). Though Ginsberg declared in a 1966 interview that "Blake is really the great radiant source of awareness" (SM 58), he was later more articulate in describing how Whitman achieved the same initiation into a truly inhabited personality: "Whitman's breakthru from conventional nationalistic identity to personal self, to subject, subjectivity, to candor of person, sacredness of the unique curious solitary personal consciousness changed written imaginative conception of the individual around the world" (DP332). Ginsberg was in effect paraphrasing Blake's advocacy for liberty of imagination in ferusalem - and tying it to Whitman-when he said this about writing in a 1987 lecture on "Meditation and Poetics": "it requires cultivation of tolerance towards one's own thoughts and impulses and ideas-the tolerance necessary for the perception of one's own mind, the kindness 
to the self necessary for acceptance of that process of consciousness and for acceptance of the mind's raw contents, as in Walt Whitman's 'Song of Myself'" (DP 264-265).

Like Blake and Whitman, Ginsberg also applauded the freedom to revel in the naked human form divine. "Key of Blake I now think is acceptance of body," he said in 1962, after a yoga acquaintance urged Blake upon him as a guru. ${ }^{18} \mathrm{~A}$ few years later he was singing the naked body in conscious imitation of Whitman: "Why am I interested in seeing myself naked?... I reach out to touch the bodies I love without fear that I'll be rejected because I'm ugly. Because I don't feel ugly now, I feel me, I feel sexy - more than that, I feel desirous, longing, lost, mad with impatience like fantastic old bearded Whitman to clasp my body to the bodies I adore . . . I love anyone's nakedness that expresses their acceptance of being born in this body in this flesh on this planet." The delight in nakedness extended to the pleasures of sex for all three poets, so Ginsberg fittingly adds with fearless explicitness, "The feelings that play in the body are its spirit, and without the body there's no place to play. . . Desire is felt in the lower abdomen" (DP 208). ${ }^{19}$ This is much in the vein of Whitman's revelation in "Song of Myself" (sec. 27) that "To touch my person to some one else's is about as much as I can stand," or, in the Calamus poem "Earth, My Likeness," that "there is something fierce and terrible in me, eligible to burst forth" (LG 52, 109). In 1969, Ginsberg was eager to acknowledge who had grandfathered in the sexual freedom clause: "A main stream of American thought embodied in our national poet Walt Whitman maintains that complete freedom of expression in this area of sexual imagery is essential to the development of our social and political system as a free-personed democracy" (DP 176). Of course, he enjoyed far more liberty than Whitman in describing his sexual joys-and insecurities.

Finally, and perhaps most importantly, Ginsberg shared the conviction of Blake and Whitman that the ideal person and the ideal society must be integrated and balanced. Body and soul cannot be sundered. No one in the nineteenth century, wrote the early sexologist Havelock Ellis in 1892, challenged the Christian tendency to favor the unseen soul over the seen body "more impressively and thoroughly, with a certain insane energy, than William Blake," and, Ellis adds, "the notion that man has a body separate from his soul is to be expunged." ${ }^{20}$ Whitman expressed this view on many occasions in the three prior decades, and Ginsberg reiterated the notion a century later. In his deft synopsis of Blake's prophetic books, "Your Reason and Blake's System," Ginsberg reduced all the dense allegory into a "relatively simple" quadruple calculus in which the body (Tharmas), emotion (Luvah), imagination (Urthona), and reason (Urizen) are balanced. This is perhaps not so distant from the balancing-act of the "four humors" of Renaissance psychology (air, 
earth, fire, water). Blake sees, Ginsberg explains, that "raising the whole man, Albion, requires a balance of imaginative faculty, emotional faculty, rational faculty, and a firm body" (DP 281). Both Blake and Whitman further simplified this process of integration by often insisting on the union of soul and body. The notion that they are separate, we have seen, Blake wanted to expunge, and Whitman said in his ' 55 preface that a great poet "favors body and soul the same" (he repeated the point verbatim in his "Song of Prudence"). The two, he says, make up the "Ensemble" of America ("One Song, America, Before I Go"), as well as every American Self - the "Personality" Whitman was so eager to publish.

As Ginsberg explains in his synopsis, in Blake's view the great enemy of the Self-its Satan-is System, forever luring us into the two most terrible of human errors: self-contradiction and self-limitation. "If you want to understand Satan's secret, understand his system of ideas," Ginsberg warned; "try to find out his system, wherefrom he comes, how he operates . . . If you have his system, then you have his secret, and every Satan has a system" (DP283). Blake said precisely this in The Marriage of Heaven and Hell, calling "System" a mode of taking advantage of and enslaving "the vulgar," resulting in the creation of a "Priesthood"- the keepers of system (WB 38). We have already noted Blake's subsequent declaration in Ferusalem: "I must Create a System, or be enslav'd by another Mans" (WB 153). Whitman later followed up with his thoroughly Blakean "caution" in his "To the States": "Once unquestioned obedience, once fully enslaved."

In just this spirit Ginsberg himself adapted "Whitman's bold personism" and "introduced Whitmanic afflatus" to his own trans-Atlantic Albion in a short essay titled "Whitman's Influence: A Mountain Too Vast to Be Seen" that he wrote in 1992 (DP 332). ${ }^{21}$ Just as Blake urged his fellow Englishmen to raise a new Albion, Ginsberg in 1972 (very near the centennial of Democratic Vistas) found himself extolling Whitman's America- "an America of pioneers and generosity" opposed to the late twentieth-century America of "selfish glooms \& exploitations ... the great betrayal of that manly America . . . made by the pseudo-heroic, pseudo-responsible masculines of Army and Industry and Advertising and Construction and Transport and toilets and Wars."22 Ginsberg ends his cri de coeur with "a farewell to all the promises of America" and the hope for "an explanation and prayer for innocence, a tearful renunciation of victory and accomplishment, a humility in the face of the 'the necessary blankness of men"' (DP 357). This is very much in the spirit of Blake's mordant cry for a new Jerusalem in Old Albion and Whitman's warning that "the future of America is in certain respects as dark as it is vast" (DV 70).

Hunter College of The City University of New York 


\section{NOTES}

1 Harold Bloom, The Anxiety of Influence: A Theory of Poetry (New York: Oxford University Press, rev. ed. 1997), 96.

2 Brooklyn Daily Times, September 29, 1855 (this review is reproduced in my edition of Whitman's Selected Poems [New York: St. Martin's, 1999], 112).

3 Frederik Schyberg, Walt Whitman (New York: Columbia University Press, 1951), 248 (the English translation, which included much revision, was made by the wife of Gay Wilson Allen, Evie Allison Allen). Schyberg also alternately observes, "Whitman's successors are, therefore, not primarily those who slavishly imitated him (they are of little interest), but those whose perception of life he had anticipated in his book and who have thus found in Leaves of Grass a natural model for what they themselves had in mind." A prior poet's "perception of life," then, can become "a natural model" for the emerging poet - as was the case for Ginsberg's inhabitation of Blake and Whitman.

4 Thomas Browne, Religio Medici, Part I, sec. 6, ed. James Winney (New York: Oxford University Press, 1963), 8.

5 Walt Whitman, The Correspondence, ed. Edwin Haviland Miller (New York: New York University Press, 1964), 2:49. John Swinton (1829-1901) was one of the rowdier denizens of Pfaff's in the Bowery; Whitman reminisced about him later: "he was like a quick blade - crossed swords with many a man there" (Horace Traubel, With Walt Whitman in Camden [various publishers, 1906-1996], 1:417); hereafter, WWC. He offered this high praise suggesting why Swinton favored subversive poets like Blake and Whitman: "stormy, tempestuous - raises a hell of a row over things - yet underneath all is nothing that is not noble, sweet, sane" (WWC 1:23). Whitman also admired the Swinton brothers for making a "darling hullabaloo" on his behalf" (2:119).

6 Algernon Swinburne, William Blake: A Critical Study, in The Complete Works, ed. Edmund Gosse and Thomas Wise (London: Heinemann, 1925-1927), 16:342, 345.

7 Found in the preface to her anthology The American Genius, ed. Edith Sitwell (London: Lehmann, 1951), viii (it contains thirty pages of Whitman). Sitwell also contrasted the two poets suggestively: "the element of Blake is Air, the element of Whitman is Earth." The "great difference" between them was that "Blake could not forgive the Fool, or believe he could enter Heaven," while Whitman "could not believe that anyone was excluded" (x-xi).

8 Letter to William Hayley, October 23, 1804, in The Complete Poetry and Prose of William Blake, ed. David Erdman (rev. ed., Berkeley: University of California Press, 1982), 757; hereafter, WB. Walt Whitman, Leaves of Grass (Philadelphia: McKay, 1891-2), 48. Hereafter, LG. Available on the Walt Whitman Archive (whitmanarchive.org).

9 Orc is considered by some Blake scholars to be an anagram for cor (Latin for heart), which is an important word in Leaves, as in the Calamus poem "Scented Herbage of My Breast": "I permit you to tell in your own way of the heart that is under you" ( $L G 96)$.

10 James Gibbons Huneker, "A Visit to Walt Whitman," in Ivory, Apes, and Peacocks (1915; rpt. Sagamore Press, 1957), 18.

11 There is also a charming 1885 letter from Rossetti to President Cleveland urging a pension for "an illustrious American named Walt Whitman"; see Letters of William Michael Rossetti ... to Anne Gilchrist, ed. Clarence Gohdes and Paull Baum (Durham: Duke University Press, 1934), 181. 
12 Allen Ginsberg, "Liner Notes to Blake Record" (Hanumen Books, 1988), in Deliberate Prose, ed. Bill Morgan (NewYork: Harper Collins, 2000), 279; hereafter, DP. Morgan shrewdly placed Ginsberg's essays on Blake and Whitman adjoining each other in this collection. In Congressional testimony in 1966 Ginsberg referred to "our prophet, Walt Whitman" (DP 68), and the same year he delivered an address on "Personal Consciousness" at a Boston church in which he referred to "the awesome prophecies about these states pronounced by Thoreau and Emerson, and elsewhere the more naked Whitman: prophecies that have now come true" (125).

13 Ginsberg's quotation is from Democratic Vistas (see the facsimile edition, edited by Ed Folsom [Iowa City: University of Iowa Press, 2010], 72); hereafter, DV. Ginsberg also joined the two poets when discussing his early stylistic influences: "I was more conscious of Christopher Smart, and Blake's Prophetic Books, and Whitman and some aspects of Biblical rhetoric" (interview in City Lights fournal [1964], in Spontaneous Mind: Selected Interviews, ed. David Carter [New York: Harper Collins, 2001], 20; hereafter, SM). Two years later, Ginsberg wrote, "[I] trained my sensibility to the eccentric modulations of long-line composition displayed by Smart, Blake, Whitman, Jeffers, Rimbaud ...” (DP 258-259).

14 Apropos the quotation from Songs of Experience, it is surprising that the bitter social criticism that ties Blake's poem cluster to Democratic Vistas has not received more emphasis. What G. E. Bentley says about Songs of Experience also fits Whitman's juvenalian prose screed: "songs of betrayal . . . cries of honest indignation and social protest ... The poems are about failure of imagination and vision ... They look down to earth rather than up to heaven" (The Stranger from Paradise: A Biography ofWilliam Blake [New Haven:Yale University Press, 2001], 144-145).

15 Donald Pease, "Blake, Whitman, Crane:The Hand of Fire," in William Blake and the Moderns, ed. Robert Berthoff and Annette Levitt (Albany: SUNY Press, 1982), 31-32.

16 Ginsberg, "Ego Confession” (1974-77), Collected Poems 1947-1997 (New York: Harper Perennial, 2006), 631; hereafter, $C P$.

17 In 1958, Ginsberg visited Blake's grave in Bunhill Fields (he also met Edith Sitwell and was delighted to learn she adored both Blake and Whitman). In 1965, he spent a few days looking at Blake's works held in the Fitzwilliam Museum (see Bill Morgan, I Celebrate Myself: The Somewhat Private Life of Allen Ginsberg [London: Viking, 2006] 272, 411; hereafter, ICM).

18 Quoted by Morgan, ICM, 364.

19 This was written for a 1965 exhibition that included a picture of a naked Ginsberg taken by Wynn Chamberlain.

20 Havelock Ellis, The New Spirit (W. Scott, 1892), 112. OscarWilde turned this view into an aphorism: "Those who see any difference between soul and body have neither""Phrases and Philosophies for the Use of the Young" (1894), in The Complete Works of Oscar Wilde (New York: Harper-Perennial, 1989), 1205.

21 Blake is not mentioned in Ginsberg's short essay "Whitman's Influence: A Mountain Too Vast to Be Seen," but Blake's notion of "Fibres of love" joining "man to man" in his new Albion (WB 146) is surely reflected in Ginsberg's assertion that Whitman's “spiritual medicine or antidote to poisonous materialism was 'adhesiveness,' a generous affection between citizens" (DP 332). I discuss Blake's views on same-sex love in the chapter on Blake in Containing Multitudes:Walt Whitman and the British Literary Tradition (NewYork: Oxford University Press, 2014), 189-196. See also Christopher Hobson, Blake 
and Homosexuality (New York: Palgrave, 2000) and his essay "What is Liberty without Universal Toleration?: Blake, Homosexuality, and the Cooperative Commonwealth," in Blake, Nation and Empire, ed. Steve Clark and David Worrall (New York: Palgrave, 2006), 136-152. Also pertinent are Queer Blake, ed. Helen Bruder and Tristanne Connolly (New York: Palgrave, 2010) and Andrew Elfenbein, Romantic Genius: The Prehistory of a Homosexual Role (New York: Columbia University Press, 1999).

22 Ginsberg wrote this essay (dated May 17-June 9, 1972), titled "The Visions of the Great Rememberer," in homage after the death of Jack Kerouac in 1969. Titled simply "The Great Rememberer," it became the introduction to Kerouac's posthumously published novel Visions of Cody (New York: McGraw-Hill, 1972). The eulogy to Kerouac casts him as very like Ginsberg himself, and self-regarding praise is also frequently encountered in Whitman's own views of his contemporaries. 